Matukhno Yulia, Master's student of the Department of Management and Economic Security, Bohdan Khmelnytsky National University of Cherkasy, Cherkasy, Ukraine

ORCID ID: 0000-0002-1657-9171

e-mail: matukhno.30@gmail.com

Kutsenko Dmytro, Postgraduate Student, Department of Management and Economic Security, Bohdan Khmelnytsky National University of Cherkasy, Cherkasy, Ukraine

ORCID ID: 0000-0001-6379-2330

e-mail: lawagens@gmail.com

\title{
The Need for Transformations of Enterprises' Mechanism of Economic Security Management in the Context of the Fourth Industrial Revolution Risks Spread
}

Abstract. Introduction. The state of economic security of the enterprise determines its ability to develop its own potential and maintain the level of competitiveness, as well as ability to counteract the negative impact of external and internal environment and prevent the risks that are characteristic of it. The number of risk factors for the normal operation of domestic enterprises has increased in the context of the trends spread of the Fourth Industrial Revolution. An important step in establishing a modern integrated economic security system is the formation of a management mechanism that will ensure the effectiveness of the process of identifying and neutralizing both traditional and emerging risks to industrial enterprises, many of which belongs to the critical infrastructure of the country and are therefore strategically important for maintaining industrial potential and maintaining the state of national security.

Purpose. The purpose of the article is to determine the vectors of transformation of the essence, functions, main stages of creating a mechanism for managing the economic security of an industrial enterprise, able to counteract the negative consequences of the risks of the Fourth Industrial Revolution.

Results. The article reveals the essence of the mechanism of economic security management and defines its main elements. It is offered to divide the functions of the mechanism of economic security management of the enterprise into preventive and anti-crisis management in order to ensure timely counteraction to the risks of the environment of the industrial enterprise. The short characteristic of the stages of industrial enterprise economic security management mechanism formation is given, features of functioning of the economic security management mechanism in the conditions of tendencies distribution of the Fourth Industrial Revolution are considered.

Conclusion. As a result of studying the basics of building a modern, risk-oriented industrial enterprise economic security management mechanism, it was found that due to its elements such as methods, resources, tools and levers of economic security, it becomes possible to effectively overcome the impact of traditional and innovative risks on corporate resources of enterprises and on the success of the process of meeting the economic interests of different groups of its stakeholders. Implementation at the applied level of the outlined stages of enterprise economic security management mechanism formation allows to apply its functionality in the future to ensure economic stability, strategic prospects and competitiveness of the business structure in the risk of the Fourth Industrial Revolution.

Keywords: economic security; management; mechanism; industrial enterprise; risk; Fourth Industrial Revolution; anticrisis management; preventive management.

\section{УДК 330.1}

Матухно Ю. С., магістрантка кафедри менеджменту та економічної безпеки, Черкаський національний університет імені Богдана Хмельницького, м. Черкаси, Україна

Куценко Д. М., аспірант кафедри менеджменту та економічної безпеки, Черкаський національний університет імені Богдана Хмельницького, м. Черкаси, Україна

\section{Необхідність трансформацій механізму управління економічною безпекою підприємств в умовах поширення ризиків Четвертої промислової революції}

\begin{abstract}
Анотація. Стан економічної безпеки підприємства визначає його здатність розвивати власний потенціал та підтримувати рівень конкурентоспроможності, а також дає змогу протидіяти негативному впливу зовнішнього та внутрішнього середовища і запобігати ризикам, які є для нього характерними. Кількість ризикових факторів для нормальної діяльності вітчизняних підприємств зросла в умовах поширення тенденцій Четвертої промислової революції. Важливим етапом налагодження роботи сучасної комплексної системи економічної безпеки є формування управлінського механізму, який забезпечуватиме ефективність процесу виявлення та знешкодження як традиційних, так і новітніх ризиків для діяльності промислових підприємств, значна частина яких належить до критичної інфраструктури краӥни, а, отже, є стратегічно важливою для збереження промислового потенціалу та підтримки стану національної безпеки держави.
\end{abstract}

Стаття надійшла до редакції: 01.10.2020

Received: 01 October 2020 
Мета статті полягає у визначенні векторів трансформації сутності, функцій, основних етапів створення механізму управління економічною безпекою промислового підприємства, здатного протидіяти негативним наслідкам реалізації ризиків Четвертої промислової революції.

У статті розкривається сутність механізму управління економічною безпекою та визначаються його основні елементи. Запропоновано розділяти функції механізму управління економічною безпекою підприємства на попереджуюче та антикризове управління з метою забезпечення своєчасної протидії ризикам середовища функціонування промислового підприємства. Надано коротку характеристику етапів формування механізму управління економічною безпекою промислового підприємства, розглянуто особливості функціонування механізму управління економічною безпекою в умовах поширення тенденцій Четвертої промислової революції.

У результаті дослідження основ побудови сучасного, ризикоорієнтованого механізму управління економічною безпекою промислового підприємства було встановлено, що завдяки таким його елементам, як методи, ресурси, засоби та важелі забезпечення економічної безпеки, стає можливим ефективне подолання наслідків впливу традиційних $i$ інноваційних ризиків на стан корпоративних ресурсів підприємства та успішність процесу задоволення економічних інтересів різних груп його стейкхолдерів. Реалізація на прикладному рівні окреслених етапів формування механізму управління економічною безпекою підприємства дає змогу так застосовувати його функціональні можливості у майбутньому, щоб забезпечити господарську стійкість, стратегічні перспективи та конкурентоспроможність бізнесструктури в умовах поширення ризиків Четвертої промислової революції.

Ключові слова: економічна безпека; управління; механізм; промислове підприємство; ризик; Четверта промислова революція; антикризове управління; попереджуюче управління.

Formulation of the problem. In the conditions of financial and economic instability, political and social crises, an effective mechanism of economic security management is a critical factor for the successful functioning of an industrial enterprise in Ukraine. The beginning and increase in the spread of trends of the Fourth Industrial Revolution led to the need to transform classical approaches to the organization of production, as well as to revise traditional management models of various activities of enterprises, including the process of ensuring their economic security. The problem of modernization and updating of conceptual bases of construction and functioning of the industrial enterprise economic security management mechanism in order to form and put into action the tool capable: to counteract effectively risks of cyberspace, information and reputation risks, threats connected with expansion of limits intelligence, automation of all without exception of activity processes of the industrial enterprises; to guarantee the rational use of the available economic potential; to maintain a high level of economic security at a reasonable cost of corporate resources to counteract external and internal risks and threats (the necessitates) and all this makes relevance of this study.

Analysis of recent research and publications. The problems of formation and functioning of the enterprise economic security management mechanism have been thoroughly studied by such scientists as S. Saloid, Ye. Naumenko, Y. Chirva, O. Nesterenko. N. Zachosova [1, 2], V. Zanora [2, 3], O. Koval [4], and A. Kovalenko [5] can be named is active researchers in the field of economic security science. At present, the theoretical and applied aspects of the formation of the mechanism of economic security management require further research to modernize the methodological foundations of its construction, as new challenges of the economic environment and risks formed and intensified by changing patterns of behavior of economic entities and forms of management catalysts for the need for structural changes in the architecture of economic entities economic security systems.
Formulation of research goals. The purpose of the article is to determine the vectors of transformation of the essence, functions, main stages of creating anenterprise economic security management mechanism, able to counteract the negative consequences of the risks of the Fourth Industrial Revolution.

Presentation of the main results of the study. An important element of the industrial enterprise economic security system is the mechanism of its management, which ensures the achievement of the goals of protection of resources of the business entity and the solution of its strategic goals and objectives. In the industrial enterprise economic security system under the mechanism should be understood arranged in a certain way the sequence of states and processes that ensure the economic security of the enterprise [6, p. 252].

The purpose of the enterprise economic security management mechanism is to ensure the required level of enterprise economic security by timely detection and neutralization of threats and negative consequences of risks to financial and economic activities of the enterprise, satisfaction of its interests and coordination of interests of stakeholders with general and strategic goals.

The criterion for the effectiveness of the enterprise economic security management mechanism is the level of its economic security. The object of management in the structure of the industrial enterprise economic security management mechanism are threats, risks, interests, corporate resources, and the subject of management is the enterprise economic security system (EESS). To achieve the desired effect industrial enterprise economic security management must be permanent and continuous [7, p. 153].

The structure of the industrial enterprise economic security management mechanism is shown in Fig. 1. Its main elements are management methods - that is a set of methods and techniques of influence of the subject of management on the object of management in order to achieve its goals. 


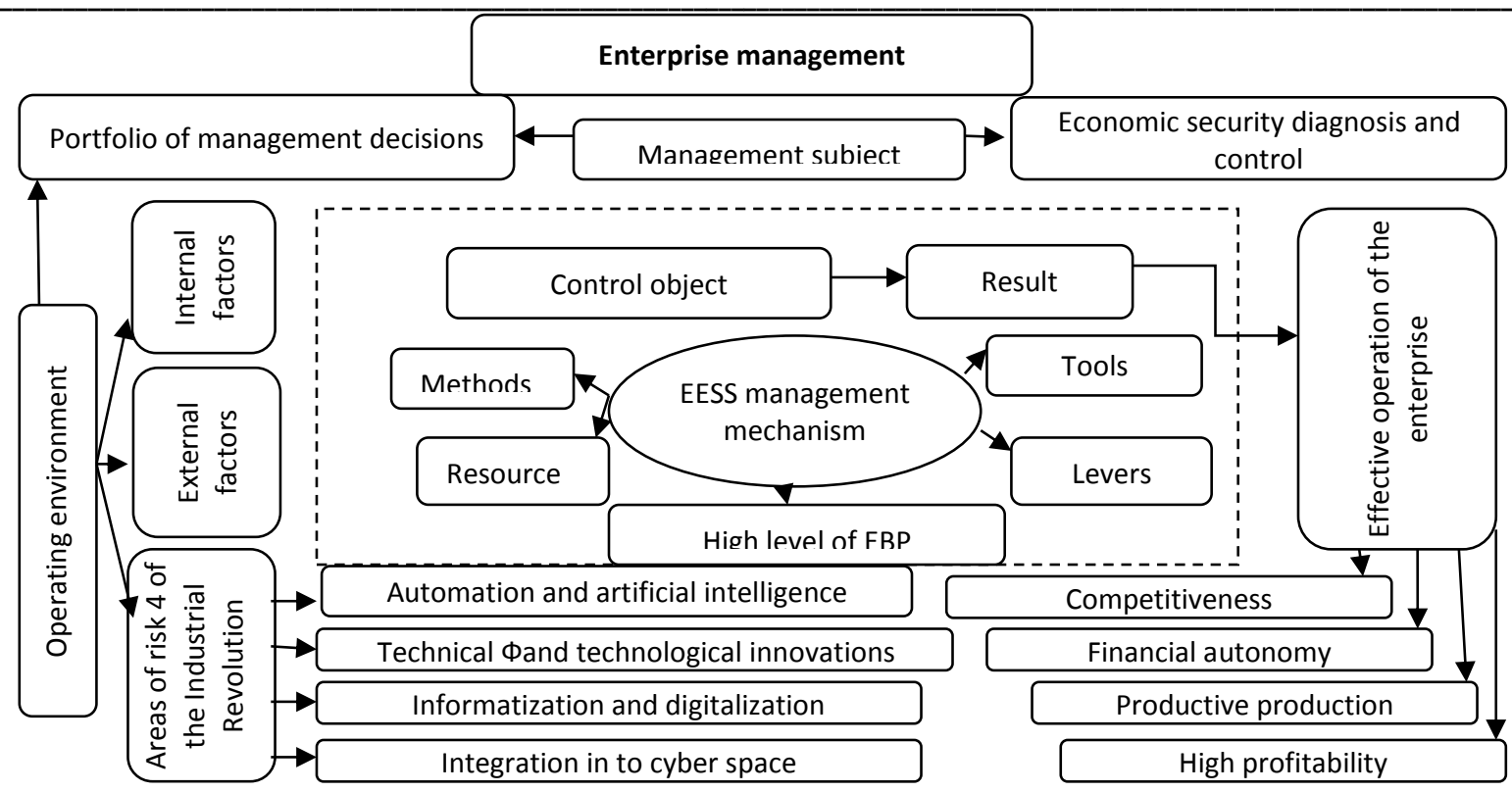

Figure 1 - The Structure of the Industrial Enterprise Economic Security Management Mechanism

Source: compiled by the authors on the basis of [9, p. 400]

The second basic element of the architecture of the industrial enterprise economic security management mechanism is its resources, which can include all the economic potential available to the entity. The role of resources is very important, without them the company is not able to achieve the strategic goal of its creation and operation. Their importance lies in the ability to develop the optimal strategy for the subject (source of formation) and to influence the external environment of the organization (the nature of use).

The next element is the control levers, with the help of which financial and economic security professionals influence the economic condition of the enterprise in order to achieve the maximum effect from the implementation of security-oriented management decisions.

For the effective functioning of the industrial enterprise economic security management mechanism requires appropriate tools to ensure the conditions of its operation $[8$, p. 400].

The industrial enterprise economic security management mechanism should be divided into preventive and anti-crisis management.

Preventive management of economic security of an industrial enterprise is the planning of strategies for its development, analysis, forecasting, planning the necessary changes and timely response to events.

The crisis management of industrial enterprise economic security should be understood as the implementation of such a management mechanism that provides rapid reduction of losses by responding immediately to events [9, p. 77; 11, p. 462].

The main advantages of the two-vector (ie one that combines anti-crisis and preventive management) industrial enterprise economic security management mechanism are:
- minimization of the probability of bankruptcy of the enterprise;

- reducing the level of threats and risks to production processes;

- stimulating innovation to maintain the level of competitiveness of the enterprise in the market;

- constant monitoring of the enterprise economic security state;

- providing management with timely and reliable information about the economic condition and financial performance of the enterprise;

- diagnosis, anticipation of dangerous, destructive situations in the enterprise and their timely localization and elimination;

- ensuring the achievement of key indicators of management efficiency in the enterprise as a whole;

- ensuring uninterrupted and effective work of all divisions of the enterprise in the direction of achieving its strategic goal [6, p. 254].

It is expedient to build the structure of the industrial enterprise economic security management mechanism on the basis of the functional-resource approach, which will allow: timely recognition of risks and threats; determine when, under what circumstances and in what areas it is necessary to carry out an aggressive offensive (implement counter-threats), use an evolutionary approach (the method of careful methodological preparation and gradual expansion of the living space of the enterprise), apply the method of adaptation or waiting [12, p. 137].

Transformations of the industrial enterprise economic security management mechanism in the conditions of the spread of the Fourth Industrial Revolution are necessary for it to meet the following requirements:

- requirement of organization - the industrial enterprise economic security management mechanism should clearly establish the place of each element and give 
it certain functions in the system to ensure stable and efficient operation of the enterprise in the presence of risks of external and internal economic environment;

- requirement of independence - separation of the industrial enterprise economic security management mechanism from the process of functioning of other mechanisms of production units, however, some tasks facing economic security management cannot be performed independently without the participation of other financial and economic systems;

- the requirement of integration, integrity and unity with the general management system of an industrial enterprise;

- the requirement of complexity - the industrial enterprise economic security management mechanism should include all the necessary elements, bodies, tools, resources, management tools designed to ensure the reliability of the economic security system;

- systemic requirement - the mechanism of economic security management is endowed with the features of an open system in which the elements of the organizational structure of the enterprise are closely connected and function.
The industrial enterprise economic security management mechanism should ensure timely detection of various dangers, threats and risks, promote timely foresight and forecast their consequences, be aimed at determining methods of collecting and providing information to top management, whose representatives will make management decisions on further security-oriented actions of the enterprise [13, p. 448].

An important aspect of the study of the industrial enterprise economic security management mechanism is the analysis of the functions that implement this mechanism. The structure of the industrial enterprise economic security management mechanism includes the following main management functions:

- planning, including programming and forecasting;

- organization of the enterprise economic security system and regulation of the economic security level;

- stimulation;

- control as part of accounting, analysis and audit [14, p. 227].

The formation of the industrial enterprise economic security management mechanism is divided into the following stages (Fig. 2) [15, p. 38]:

study of the specifics of production, the segment ienterprise covers in the market; defining the mission and objectives of activities in the context of competitive development

assessment of the level of economic security of the enterprise for each functional component, audit of corporate resources to ensure the level of their protection and analysis of their compliance with the identified threats and risks

modeling of theindustrial enterprise economic security management mechanism, search of resource maintenance of its functioning and development

introduction of the formed mechanism, its interaction to the general management of the enterprise and an estimation of a level of its efficiency

Figure 2 - Stages of Formation of the Industrial Enterprise Economic Security Management Mechanism

Source: compiled by the authors on the basis of [15, p. 38]

Development of the industrial enterprise economic security management mechanism provides: a preparatory stage (studying of specificity of production processes, the analysis of external and internal environments, and also audit of the available system of security or practice concerning maintenance of economic security at the enterprise); modeling of a new or improvement of the existing economic security system; choice of option for organizing the economic security service; approval and coordination of information and analytical support for the functioning of the security system; development of scenarios for normal and emergency economic and production situations; audit, monitoring and control (based on the results of which there are updates of the enterprise economic security system and qualitative transformations of the management mechanism) $[12$, p. 39].
The industrial enterprise management for the effective economic securitymanagement in the conditions of tendencies distribution of the Fourth Industrial Revolution can apply the following measures:

- legal measures (application of regulatory documents relating to all areas of the enterprise);

- financial and economic measures(ensuring financial independence and financial stability);

- force measures(measures to protect all types of enterprise resources from the actions of competitors);

- informational measures (collection and analysis of necessary information, crisis prevention);

-technical and technological measures (updating of production assets);

- innovative measures (application of innovative technologies by the enterprise) [10, p. 142]. 
The company's management identifies strategic issues related to the economic security management. Based on this, the basic strategy of security-oriented development of the business entity is chosen. Further, the purpose of creating such a functional unit as the security service (economic security) of the enterprise, which to perform its main functions involves, if necessary, other departments provided by the organizational structure should be concretized. The economic security service of the enterprise manages EESS at the strategic, tactical and operational levels. To ensure the effectiveness of the industrial enterprise economic security management mechanism it is necessary to introduce an operational system for monitoring its level, which will allow:

- provide management with timely and reliable information about the state of economic security of the enterprise;

- to carry out complex diagnostics of external and internal environments of functioning of the enterprise and to prevent dangerous, destructive situations in its activity for their fast and effective prevention, localization and liquidation;

- to form key indicators of economic security management efficiency;

- to ensure uninterrupted and mutually beneficial cooperation of all divisions of the enterprise in the direction of safety-oriented management;
- use the tools of management decisions to form from the existing risks for the enterprise a set of opportunities, rather than threatening factors for its economic security state $[15$, p. 464].

Conclusions. As a result of studying the basics of building a modern, risk-oriented industrial enterprise economic security management mechanism, it was found that due to its elements such as methods, resources, tools and levers of economic security, it becomes possible to effectively overcome the impact of traditional and innovative risks on corporate resources of enterprises and on the success of the process of meeting the economic interests of different groups of its stakeholders. Implementation at the applied level of the outlined stages of enterprise economic security management mechanism formation allows to apply its functionality in the future to ensure economic stability, strategic prospects and competitiveness of the business structure in the risk of the Fourth Industrial Revolution.

Prospects for further research are connected with the need to form a theoretical and methodological foundations of preventive and crisis management in the structure of the industrial enterprise economic security management mechanism.

\section{References:}

1. Zachosova, N. \& Herasymenko, O. \& Shevchenko, A. (2018). Risks and possibilities of the effect of financial inclusion on managing the financial security at the macro level. Investment Management \& Financial Innovations, 15 (4), $304-319$ [in English].

2. Zachosova, N. \& Babina, N. \& Zanora, V. (2018). Research and methodological framework for managing the economics security of financial intermediaries in Ukraine. Banks and Bank Systems, 13 (4), 119-130 [in English].

3. Zanora, V. O. (2011). Ekspertnyj metod analizu ryzykiv promyslovogho pidpryjemstva. Upravlinnja proektamy ta rozvytok vyrobnyctva, 2(38), 95-101 [in Ukrainian].

4. Koval, O. V. (2020). Strategic management of economic security system of business entities: theoretical aspects. Bulletin of the Cherkasy National University. Economic Sciences, 1, 40-47 [in English].

5. Kovalenko, A. (2020). Personnel security as an element of human resources (personnel) policy in the economic and financial security system of the business entity. European journal of economics and management, 6 (1), 100-106 [in in English].

6. Salojid, S. V. (2017). Mekhanizm upravlinnja ekonomichnoju bezpekoju pidpryjemstva: teoretychnyj aspekt. Ekonomichnyj visnyk Nacionaljnogho tekhnichnogho universytetu Ukrajiny "Kyjivsjkyj politekhnichnyj instytut», 14, 250-254 [in Ukrainian].

7. Illjashenko, O. V. (2015). Poghorelov Ju. S. Peredumovy formuvannja mekhanizmu upravlinnja systemoju ekonomichnoji bezpeky pidpryjemstva. Visnyk Khmeljnycjkogho nacionaljnogho universytetu, 4 (2), 151-165 [in Ukrainian].

8. Shatokhin, A. L. \& Ighnashkina, T. B. (2014). Sutnistj ta skladovi element mekhanizmu upravlinnja ekonomichnoju bezpekoju pidpryjemstva. Biznes-inform, 2, 396-402 [in Ukrainian].

9. Fedotova, T. A. \& Bilousova, D. V. (2016). Upravlinnja ekonomichnoju bezpekoju. Aktualjni problem ekonomiky ta upravlinnja v umovakh systemnoji kryzy [Actual problems of economy and management in the conditions of systemic crisis], Vseukrajinsjkoji naukovo-praktychnoji konferenciji [All-Ukrainian scientific-practical conference]. Ljviv: Ljvivsjkyj instytut MAUP, 675 [in Ukrainian].

10. Vasyljjev, O. V. (2013). Formuvannja systemy upravlinnja ekonomichnoju bezpekoju promyslovykh pidpryjemstv. Ekonomichnyj analiz, 2 (14), 138-145 [in Ukrainian].

11. Naumenko, Je. Ju. (2017). Mekhanizm upravlinnja ekonomichnoju bezpekoju pidpryjemstva v umovakh kryzy. Molodyj vchenyj, 6, 462466 [in Ukrainian].

12. Kolodjazhna, I. V. \& Bukrina, K. A. (2019). Ekonomichna bezpeka v systemi stalogho funkcionuvannja pidpryjemstva. Naukovyj visnyk Uzhghorodsjkogho nacionaljnogho universytetu, 23 (1), 135-140 [in Ukrainian].

13. Onishhenko, M. L. \& Sjurkalo, B. I. (2018). Osoblyvosti mekhanizmu upravlinnja ekonomichnoju bezpekoju pidpryjemstva. Ekonomika i suspiljstvo, 16, 446-452 [in Ukrainian].

14. Orlyk, O. V. (2015). Mekhanizm upravlinnja finansovo-ekonomichnoju bezpekoju pidpryjemstva ta jogho osnovni skladovi. Finansovokredytna dijaljnistj: problem teoriji ta praktyky, 2, 222-232 [in Ukrainian].

15. Koleshnja, Ja. O. (2016). Rozrobka mekhanizmu upravlinnja ekonomichnoju bezpekoju malykh ta serednikh pidpryjemstv. Problemy $i$ perspektyvy rozvytku pidpryjemnyctva, 3(1), 36-41 [inUkrainian]. 